\title{
Weathering deterioration in pre-harvest of soybean seeds: physiological, physical, and
}

\section{morpho-anatomical changes}

\author{
Daniel Teixeira Pinheiro* ${ }^{(}$, Denise Cunha Fernandes dos Santos Dias ${ }^{\circledR}$, André Dantas de Medeiros ${ }^{\circledR}$, João Paulo Oliveira Ribeiro ${ }^{\circledR}$, \\ Felipe Lopes da Silva® Laércio Junio da Silva®
}

Universidade Federal de Viçosa - Depto. de Agronomia, Av. PH Rolfs s/n - 36570-900 - Viçosa, MG - Brasil.

*Corresponding author <pinheiroagroufv@gmail.com>

Edited by: Lincoln Zotarelli

Received June 04, 2020

Accepted November 25, 2020
ABSTRACT: Successive cycles of water absorption and loss favor weathering deterioration, one of the main factors that affect the quality of soybean seeds. This study evaluated the physiological, physical, and morpho-anatomical changes in soybean seeds under weathering deterioration at the pre-harvest phase. Six soybean cultivars (BMX Apolo, DM 6563, NS 5959, NA 5909, BMX Potência, and TMG 1175) were produced in a greenhouse and underwent weathering deterioration through a rainfall simulation system, applying $0,60,120$, and 180 $\mathrm{mm}$ of precipitation at pre-harvest phase. Each rainfall level was divided into two applications at an interval of $72 \mathrm{~h}: 60 \mathrm{~mm}(30+30), 120 \mathrm{~mm}(60+60)$, and $180 \mathrm{~mm}(90+90)$. After harvest, the seeds were evaluated for germination, vigor, physical and morpho-anatomical properties. Weathering deterioration induced by simulated rainfall at the pre-harvest phase contributes to the reduction in soybean seed germination and vigor and is conditioned by the soybean genotype. The increase in intensity of simulated rainfall led to a more significant weathering damage in seeds, as evidenced by the X-ray and tetrazolium test. Cultivars DM 6563 and BMX Potência were more susceptible, while NA 5909 was less susceptible to weathering deterioration (especially at the highest level; $120 \mathrm{~mm}$ and $180 \mathrm{~mm}$ ). Anatomical changes caused by weathering deterioration lead to cell compaction and rupture, mainly in the cell layers of the hourglass and parenchyma, forming intracellular spaces. The presence of weathering damage caused a reduction in physiological soybean seed quality.

Keywords: Glycine max L., X-ray, anatomy, precipitation, physiological quality

\section{Introduction}

Soybean (Glycine $\max$ L.) seeds are highly susceptible to environmental stresses at pre-harvest, such as the occurrence of rains or daily changes in relative humidity, especially associated to high temperatures (Shu et al., 2020). After physiological maturity (R7 stage), these conditions accelerate seed deterioration, which depends on the genotype and environment (Bhatia et al., 2010), reducing seed quality, mainly in tropical regions with high rainfall levels (Malik, 2013; Marcos-Filho, 2016; Santachiara et al., 2017).

Weathering deterioration contributes to the reduction of seed germination and vigor and physiological tests, such as germination, tetrazolium, electrical conductivity, among others, are commonly used to evaluate the weathering process (Forti et al., 2013; Castro et al., 2016; Huth et al., 2016; França-Neto and Krzyzanowski, 2019). Although efficient, these tests could be complemented by other evaluations, such as the assessment of physical attributes of seeds.

Weathered soybean seeds often show characteristic wrinkles on the coat surface and are generally related to physiological potential reduction (Forti et al., 2013). In this sense, the X-ray test, a faster and non-destructive analysis, has arisen as an alternative and efficient technique for the physical analyses of seeds (Rahman and Cho, 2016; Medeiros et al., 2020). Forti et al. (2013) reported that soybean seeds with weathering damage had lower germination and vigor, due to deterioration in the field. These authors reported that X-ray test and scanning electron microscopy (SEM) are effective to evaluate the effects of weathering damage. In this context, Image ${ }^{\circledR}$ is a free software program that has been used for the semi-automated analysis of radiographic images of seeds, allowing rapid results with reduced subjectivity (Baek et al., 2020). However, few studies evaluate the automated analyses, such as tissue density or morpho-anatomical characterization in soybean seeds subjected to weathering deterioration. These analyses could provide a better understanding of the mechanisms involved in this process.

Castro et al. (2016) studied soybean seed deterioration at pre-harvest (R8) with simulated rainfall $(30 \mathrm{~mm})$ and concluded that pods dried out rapidly and there was little weathering damage. However, possibly, the application of higher levels of precipitation in a gradual manner may provide more evident weathering effects than only one application in a concentrated manner. Furthermore, the evaluation of different genotypes under weathering deterioration induced by simulated rainfall could be an important tool for genetic breeding programs.

This study assessed physiological attributes and associated them to physical attributes through X-ray tests in seeds of different soybean cultivars under weathering deterioration in the pre-harvest phase. We also performed the morpho-anatomical characterization of the seeds with and without weathering damage. 


\section{Materials and Methods}

\section{Location, plant matter, sowing, and fertilization}

The study was conducted in Viçosa, Minas Gerais, Brazil $\left(20^{\circ} 45^{\prime} 17^{\prime \prime} \mathrm{S}, 42^{\circ} 52^{\prime} 57^{\prime \prime} \mathrm{W}\right.$, altitude of $649 \mathrm{~m}$ a.s.1.). Six soybean cultivars (commercially important and normally produced in areas subject to excessive rainfall) of indeterminate growth habit and different maturity groups (MG) were used: DM 6563 RFS IPRO $(\mathrm{MG}=6.3), \mathrm{BMX}$ Apolo RR (MG = 5.5), BMX Potência $(\mathrm{MG}=6.7)$, NA $5909 \mathrm{RG}(\mathrm{MG}=6.2)$, NS $5959 \mathrm{IPRO}$ $(\mathrm{MG}=5.9)$, and TMG $1175 \mathrm{RR}(\mathrm{MG}=7.5)$.

The experiment was conducted in a greenhouse and seeds were sown in $3.5 \mathrm{dm}^{3}$ plastic pots containing soil with a sandy clay texture. After the soil chemical analysis, fertilization was carried out at planting, consisting of the application of $200,350,200,40,0.81$, $1.33,1.55,3.66,0.15$, and $4.0 \mathrm{mg} \mathrm{dm}^{-3}$ of $\mathrm{N}, \mathrm{P}, \mathrm{K}, \mathrm{S}, \mathrm{B}$, $\mathrm{Cu}, \mathrm{Fe}, \mathrm{Mn}, \mathrm{Mo}$, and $\mathrm{Zn}$, respectively.

Six seeds were sown in each pot and plants were thinned at the V1 stage, keeping the two most vigorous seedlings. At 30 and 45 days after sowing, fertilizer was side dressed in parcels, with an application of $0.12 \mathrm{~g} \mathrm{dm}^{3}$ of $\mathrm{N}(0.06 \mathrm{~g}$ at 30 days $+0.06 \mathrm{~g}$ at 45 days) and $0.05 \mathrm{~g}$ $\mathrm{dm}^{3}$ of $\mathrm{K}(0.025 \mathrm{~g}$ at 30 days $+0.025 \mathrm{~g}$ at 45 days). The plants were irrigated daily up to the R8 stage according to need, aiming to keep soil moisture near field capacity. The irrigation management was determined by tensiometry and a practical tact-appearance method to keep soil moisture at field capacity. Six tensiometers (1 per cultivar) were inserted into the soil at a depth of 20 $\mathrm{cm}$. The soil moisture values were obtained by reading the tensiometer (matrix potential) and plotted the readings on the soil-water characteristic curve. The crop treatment was basically soil scarification at V2 stage.

\section{Methodology for application of simulated rainfall}

A micro spray system was set up using the Agrojet model NA1 (microdroplets of 40 microns, flow 7.14 $\mathrm{L} \mathrm{h}^{-1}$, working pressure 10-50 $\mathrm{m} \mathrm{H}_{2} \mathrm{O}$, and hourly precipitation amount $3.5 \mathrm{~mm}$ ) over two plant benches. The spacing between micro spray nozzles was $0.5 \mathrm{~m}$, with 12 per bench. The water used in the application of precipitation was kept in a tank and the system (tubing + micro sprayers) was supplied using a pump, SOMAR model SHP-35 (0.5 hp, maximum pressure of $35 \mathrm{~m} \mathrm{H}_{2} \mathrm{O}$, maximum flow of $2.1 \mathrm{~m}^{3} \mathrm{~h}^{-1}$, and $3400 \mathrm{rpm}$ ).

A preliminary test was performed consisting of system operation for $30 \mathrm{~min}$ and water collection in containers distributed at random on the plant benches. After that, the volumes of water collected in the containers were measured to calculate the Christiansen Uniformity Coefficient (CUC) (Mantovani et al., 2009). The CUC calculated was $90.1 \%$, considered excellent by those authors, within the range of 80 to $100 \%$. From these definitions, it was determined that $15 \mathrm{~min}$ of system operation allowed the accumulation of $20 \mathrm{~mm}$ of precipitation.

To promote seed humidification and induce weathering deterioration three precipitation levels were defined (60 mm, $120 \mathrm{~mm}$, and $180 \mathrm{~mm}$ ) and were applied when plants reached the R8 stage $195 \%$ of pods were dry) (Castro et al., 2016). Each level was divided into two applications at an interval of $72 \mathrm{~h}$ : $60 \mathrm{~mm}(30$ $\mathrm{mm}+30 \mathrm{~mm}), 120 \mathrm{~mm}(60 \mathrm{~mm}+60 \mathrm{~mm})$, and 180 $\mathrm{mm}(90 \mathrm{~mm}+90 \mathrm{~mm})$. In the control treatment $(0 \mathrm{~mm})$, there was no application of simulated rainfall.

During the application of simulated precipitations, the temperature and relative humidity data were collected in the greenhouse. The mean minimum and maximum air temperatures during the application period were $20.2{ }^{\circ} \mathrm{C}$ and $40.5{ }^{\circ} \mathrm{C}$, respectively. The minimum and maximum relative humidity values were $25.9 \%$ and $81 \%$, respectively.

Soybean pods were collected at the R8 stage at $24 \mathrm{~h}$ and $72 \mathrm{~h}$ after application of the simulated precipitation to monitor water absorption by the pods and seeds. During this period, the mean minimum and maximum air temperatures were $22.4^{\circ} \mathrm{C}$ and $41.2^{\circ} \mathrm{C}$, respectively. The minimum and maximum relative humidity levels were 28.6 and $87 \%$, respectively.

The seed moisture content was also evaluated in the control treatment $(0 \mathrm{~mm})$. For all treatments, pods were harvested at $72 \mathrm{~h}$ after application of the precipitation levels, except for the control treatment (0 mm), which was harvested when the seeds reached approximately $15 \%$ moisture at the R8 stage. The pods were collected manually and separated from the seeds, which were placed in the shade in the laboratory environment until reaching hygroscopic equilibrium. The seeds from each treatment were then placed in paper bags and the laboratory analyses described below were performed.

\section{Physiological evaluations}

Germination: conducted with four replications of 50 seeds in rolls of paper towel (moistened at 2.5 times the weight of dry paper) kept at $25{ }^{\circ} \mathrm{C}$ in a germinator $(8 \mathrm{~h}$ of photoperiod). The mean percentage of normal seedlings was evaluated on the $8^{\text {th }}$ day after sowing (ISTA, 2020).

First germination count: conducted together with the germination test. The mean percentage of normal seedlings was evaluated at five days after sowing (ISTA, 2020).

Accelerated aging: conducted with four replications of 50 seeds placed on a screen accompanying a "gerbox" plastic germination box containing $40 \mathrm{~mL}$ of water. The germination box was kept in BOD at $41{ }^{\circ} \mathrm{C}$ for $48 \mathrm{~h}$. Afterwards, the seeds were placed to germinate at 25 ${ }^{\circ} \mathrm{C}$, as described for the first germination count, and evaluation was made on the $5^{\text {th }}$ day (Marcos-Filho, 2015).

Seedling emergence: conducted with four replications of 25 seeds sown in trays containing soil and 
sand in a 3:1 ratio in a greenhouse. The soil was irrigated whenever necessary to keep it near field capacity. Daily counts of normal emerged seedlings were conducted until stabilization, calculating the emergence percentage (Maguire, 1962).

Tetrazolium test: conducted with four replications of 50 seeds that were pre-conditioned in a paper towel (moistened with distilled water) for $16 \mathrm{~h}$ at $25^{\circ} \mathrm{C}$ in a seed germinator. After that, the seeds were placed in plastic cups and submerged in $50 \mathrm{~mL}$ of tetrazolium solution (2-3-5, triphenyl tetrazolium chloride) at $0.075 \%$ and kept at $40{ }^{\circ} \mathrm{C}$ for $3.5 \mathrm{~h}$ in an incubator in the dark. After the staining process, the seeds were washed with running water and were classified individually regarding viability, according to the criteria proposed by França-Neto et al. (1999). In addition, the percentage of weathering damage was evaluated, characterized by symmetric lesions in the cotyledons and the embryonic axis.

Corrected vigor index (CVI): conducted with four replications of 20 seeds were distributed in a line placed on the upper third of two sheets of paper for germination and covered with a third sheet. The paper had been moistened with water at the amount of 2.5 times its dry weight. The paper was rolled and the rolls were kept at $25^{\circ} \mathrm{C}$ in a germinator for three days. Then images of the seedlings were made by a scanner (HP, Scanjet 200) with 200 dpi resolution. The images were placed in the Image ${ }^{\circledR}$ software and adjusted for scale; then, the hypocotyl and the roots of each seedling were individually demarcated. From these data, the corrected vigor index, proposed by Medeiros and Pereira (2018), was generated for each replication, with the results expressed in dimensional values ranging from 1 to 1000 in which the higher the value, the better the performance for that trait.

\section{Physical evaluations (X-ray test)}

Five replications of 20 seeds were fastened in an orderly manner on plastic adhesive. Radiographic images were then generated using a Faxitron device, model MX-20, placing the seeds under radiation for $5 \mathrm{~s}$ at $23 \mathrm{kV}$ and a focal distance of $41.6 \mathrm{~cm}$. The digital images generated were saved to a computer and analyzed in a semiautomated manner by the Image ${ }^{\circledR}$ software to obtain the following variables:

Integrated density: the sum of the pixel values in the image or selection, equivalent to the product of the seed area and the mean gray value of the pixels of the selection.

Weathering damage: we calculated the percentages of seeds without wrinkling (Figure 1A) or those characterized by wrinkling (Figure $1 \mathrm{~B}$ ) of the seed coat in the region opposite the hilum.

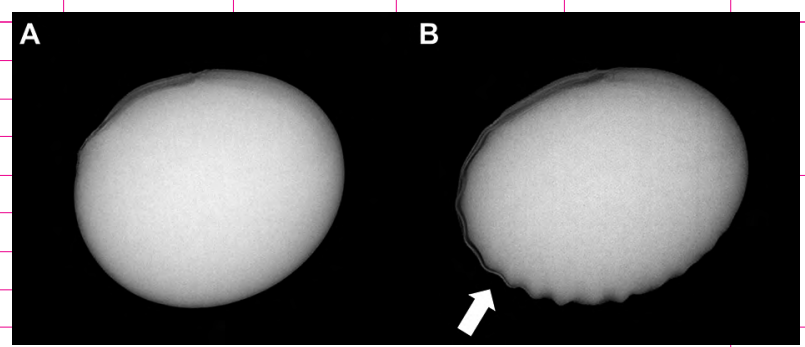

Figure 1 - X-ray images in gray scale of soybean seeds cv. BMX Potência, without $(A)$ and with $(B)$ weathering damage. Arrow = Wrinkling of the seed coat, characterizing weathering damage.

\section{Morpho-anatomical characterization}

Soybean seeds with and without visible weathering damage were photographed at high resolution for external characterization. The same seeds were then fixed in FAA (formaldehyde, acetic acid, $50 \%$ ethanol $1: 1: 18$ by volume) and stored in $70 \%$ ethanol (Johansen, 1940). The samples were dehydrated in gradations of ethyl alcohol and embedded in methacrylate historesin. Cross sections (highlighting seed coat and surface of the cotyledons) of 5- $\mu \mathrm{m}$ thickness were cut in a rotary microtome using glass razors. The sections were stained with toluidine blue $\mathrm{pH} 4.0$ (O'Brien and McCully, 1982) for structural characterization. Slides were set up in synthetic resin.

A light microscope was used for the analyses and the images, with a U-Photo system and connected digital camera.

\section{Experimental design and statistical analysis}

The experimental design was completely randomized in a $6 \times 4$ factorial arrangement, consisting of six cultivars and four levels of simulated precipitation (0 mm, $60 \mathrm{~mm}, 120 \mathrm{~mm}$, and $180 \mathrm{~mm}$ ), with four replications. The analysis of variance (ANOVA) was performed on the data. After confirming the normality of error distribution by the Shapiro-Wilk test, the mean values of the treatments were compared by the Tukey test at $5 \%$ probability.

The multivariate principal component analysis (PCA) was also performed for all the traits evaluated. The a " $\mathrm{n} \times \mathrm{p}$ " matrix was obtained, where " $\mathrm{n}$ " corresponds to the number of treatments $(n=24)$, and " $\mathrm{p}$ " is the number of variables analyzed $(\mathrm{p}=7)$. The eigenvalues and eigenvectors were calculated from the covariance matrices and registered in two-dimensional plots (scatter plot of categories and correlation circle), generated from the Factoextra package (Kassambara and Mundt, 2016). The Pe arson's correlation (r) was performed for data of the pod and seed moisture content test ( $24 \mathrm{~h}$ and $72 \mathrm{~h})$, for the tetrazolium test (viability and weathering damage), and for the data obtained from the other evaluations. 


\section{Results}

Significant positive correlations $(p<0.05)$ were observed between the seed moisture content and the pod moisture content $24 \mathrm{~h}$ after application of the three levels of precipitation (60 mm, $120 \mathrm{~mm}$, and $180 \mathrm{~mm}$ ) (Figure 2A). In contrast, within the interval of $72 \mathrm{~h}$ after application, there was no significant correlation between seed moisture and pod moisture at any of the levels of simulated rainfall applied (Figure 2B).

The moisture content of the seeds and pods 24 $\mathrm{h}$ after application of precipitation ranged from $14 \%$ $(0 \mathrm{~mm})$ to $22 \%$ (at the highest level of precipitation $180 \mathrm{~mm}$ ) (Figure 2A). Within the interval of $72 \mathrm{~h}$, the seeds had from $12 \%$ to $13.5 \%$ moisture at the different precipitation levels (Figure $2 \mathrm{~B}$ ). Therefore, a considerable reduction in moisture was observed in seeds and in pods at $72 \mathrm{~h}$ after application of precipitation.

There was a significant interaction between the precipitation levels and the cultivars for germination, first germination count, accelerated aging, seedling emergence, and CVI. The seed germination of all cultivars was reduced with the application of simulated
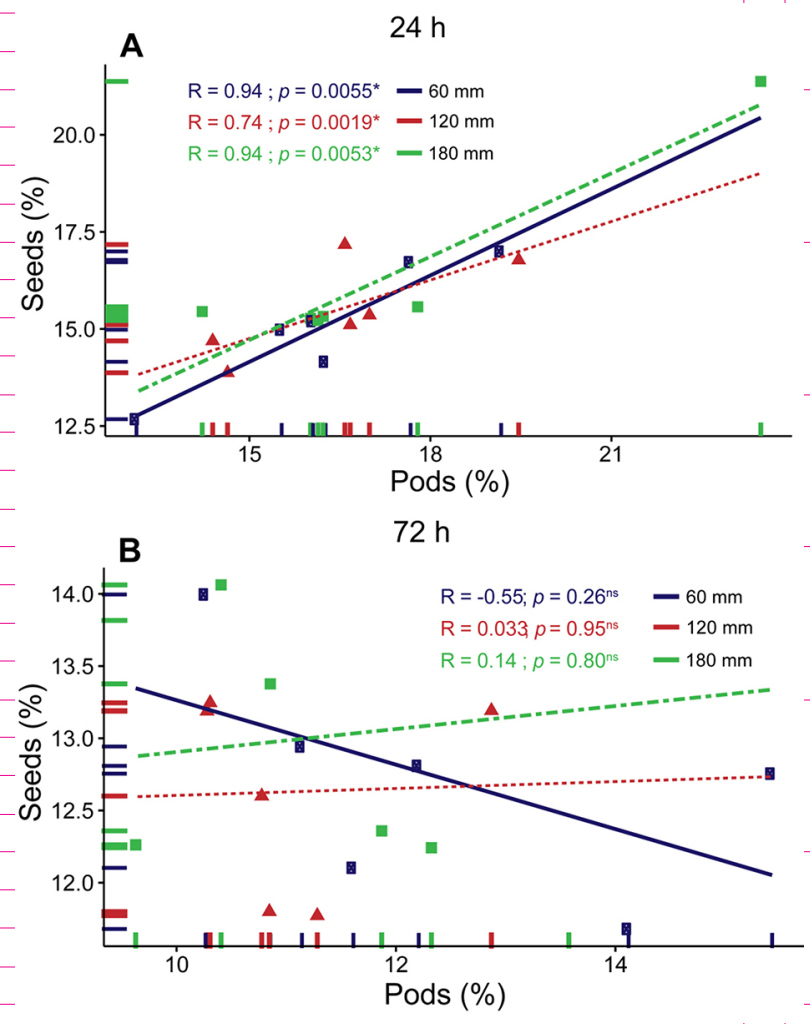

Figure 2 - Pearson's correlation obtained between the moisture content of the soybean seeds and pods under different levels of precipitation at 24 (A) and 72 (B) h after application of simulated rainfall. ${ }^{\mathrm{ns}},{ }^{*}=$ not significant and significant by the test $(p<$ 0.05), respectively. rainfall levels. The germination of cultivars DM 6563, BMX Apolo, and BMX Potência decreased by 15, 16, and 30 percentage points (p.p.), respectively, comparing the highest level $(180 \mathrm{~mm})$ to the control $(0 \mathrm{~mm})$. Cultivars NS 5959, NA 5909, and TMG 1175 kept germination percentages above $80 \%$ even at the level of $180 \mathrm{~mm}$. Significant reductions were observed in the percentage of normal seedlings of first germination count for all the cultivars with the application of the precipitation levels. These reductions were more evident in cultivars DM 6563 and BMX Potência with 27 p.p. and 34 p.p., respectively, comparing the highest precipitation level $(180 \mathrm{~mm})$ with the control $(0 \mathrm{~mm})$. Although the reduction for TMG 1175 was significant, it was only 12 p.p. (Table 1).

In the accelerated aging test, there were significant differences for seed vigor among all the cultivars even in the control treatment $(0 \mathrm{~mm})$. With the application of simulated rainfall, all cultivars showed a significant reduction in normal seedlings after the aging test, especially at the levels 120 and $180 \mathrm{~mm}$. The comparison of the highest level of precipitation $(180 \mathrm{~mm})$ with the control $(0 \mathrm{~mm})$, reduction in vigor was the greatest for seeds of cultivar BMX Apolo, at 40 p.p. (Table 1).

Except for NA 5909 and NS 5959, seedling emergence was significantly reduced with precipitation. The other cultivars exhibited similar responses, with a reduction of approximately 15 p.p., comparing the highest precipitation level $(180 \mathrm{~mm})$ with the control $(0$ $\mathrm{mm}$ ) (Table 1).

The increase in the precipitation levels decreased the corrected vigor index (CVI) for all cultivars, confirming the results obtained in the other tests. This reduction was observed especially in DM 6563, BMX Apolo, and BMX Potência. The CVI had a significant reduction for cultivar TMG 1175 only at the highest precipitation level (180 $\mathrm{mm})$.

According to the tetrazolium test, weathering deterioration caused a reduction in viability (Figure 3A) and a significant increase in weathering damage (Figure $3 \mathrm{~B})$ in soybean seeds. Reduction in seed viability was most evident in cultivars DM 6563 and BMX Potência, with up to 40 p.p. comparing to the control (Figure 3A).

TMG 1175 was the only cultivar in which viability and weathering damage of seeds did not change with precipitation (Figures $3 \mathrm{~A}$ and $3 \mathrm{~B}$ ). These results corroborate those observed in vigor tests (Table 1) where, in general, seeds of cultivars DM 6563 and BMX Potência showed greater susceptibility to weathering deterioration, while those of TMG 1175 showed less susceptibility.

As seed viability declined, weathering damage was higher (Figure 3C). In this context, a significant negative correlation between weathering damage and seed viability appeared for the three precipitation levels applied $(60,120$, and $180 \mathrm{~mm})$. Therefore, as deterioration intensified in soybean seeds, weathering damage was observed, which was characterized by striation on the side opposite to the hilum, as well as a greater proportion and intensity of plant tissue with 
Table 1 - Mean values obtained in the tests of first germination count, accelerated aging, seedling emergence, and corrected vigor index (CVI) of six soybean cultivars under different levels of precipitation.

\begin{tabular}{|c|c|c|c|c|c|c|}
\hline & $\begin{array}{c}\text { DM } \\
6563\end{array}$ & $\begin{array}{l}\text { BMX } \\
\text { Apolo }\end{array}$ & $\begin{array}{c}\text { BMX } \\
\text { Potência }\end{array}$ & $\begin{array}{c}\text { NA } \\
5909\end{array}$ & $\begin{array}{c}\text { NS } \\
5959\end{array}$ & $\begin{array}{c}\text { TMG } \\
1175\end{array}$ \\
\hline Precipitation (mm) & \multicolumn{6}{|c|}{ Germination (\%) } \\
\hline 0 & $93 \mathrm{Aa}$ & $91 \mathrm{Aa}$ & $90 \mathrm{Aa}$ & $92 \mathrm{Aa}$ & $96 \mathrm{Aa}$ & $92 \mathrm{Aa}$ \\
\hline 60 & $88 \mathrm{Abab}$ & $88 \mathrm{Aab}$ & $79 \mathrm{Bb}$ & $84 \mathrm{Bab}$ & $94 \mathrm{Aa}$ & $90 \mathrm{Aa}$ \\
\hline 120 & $81 \mathrm{Bab}$ & $78 \mathrm{Bb}$ & $77 \mathrm{Bb}$ & $85 \mathrm{Bab}$ & 87 Abab & $89 \mathrm{Aa}$ \\
\hline 180 & $78 \mathrm{Bb}$ & $75 \mathrm{Bb}$ & $60 \mathrm{Cc}$ & $86 \mathrm{Ba}$ & $83 \mathrm{Bab}$ & $80 \mathrm{Bab}$ \\
\hline Mean & 85 & 83 & 77 & 86 & 90 & 88 \\
\hline CV (\%) & \multicolumn{6}{|c|}{6.13} \\
\hline Precipitation (mm) & \multicolumn{6}{|c|}{ First germination count (\%) } \\
\hline 0 & $92 \mathrm{Aa}$ & $85 \mathrm{Aa}$ & $87 \mathrm{Aa}$ & $88 \mathrm{Aa}$ & $88 \mathrm{Aa}$ & $89 \mathrm{Aa}$ \\
\hline 60 & $79 \mathrm{Bb}$ & $79 A b$ & $72 \mathrm{Bb}$ & $79 \mathrm{Bb}$ & $82 \mathrm{Aab}$ & $88 \mathrm{Aa}$ \\
\hline 120 & $68 \mathrm{Cc}$ & $72 \mathrm{Bb}$ & $68 \mathrm{Bc}$ & $79 \mathrm{Bb}$ & $71 \mathrm{Bb}$ & $85 \mathrm{Aa}$ \\
\hline 180 & $65 \mathrm{Cc}$ & $65 \mathrm{Bc}$ & $53 \mathrm{Cd}$ & $77 \mathrm{Ba}$ & $70 \mathrm{Bb}$ & $77 \mathrm{Ba}$ \\
\hline Mean & 76 & 75 & 70 & 81 & 78 & 85 \\
\hline CV (\%) & \multicolumn{6}{|c|}{9.17} \\
\hline Precipitation (mm) & \multicolumn{6}{|c|}{ Accelerated aging (\%) } \\
\hline 0 & $76 \mathrm{Abc}$ & $86 \mathrm{Aa}$ & $72 \mathrm{Ac}$ & $74 \mathrm{Ac}$ & $82 \mathrm{Aabc}$ & $84 \mathrm{Aab}$ \\
\hline 60 & $58 \mathrm{Bc}$ & $69 \mathrm{Bab}$ & $61 \mathrm{Bbc}$ & $65 \mathrm{Bbc}$ & $74 \mathrm{Ba}$ & $68 \mathrm{Bab}$ \\
\hline 120 & $55 \mathrm{Bb}$ & $65 \mathrm{Ba}$ & $60 \mathrm{Bab}$ & $59 \mathrm{Bab}$ & $66 \mathrm{Ca}$ & $65 \mathrm{Ba}$ \\
\hline 180 & $55 \mathrm{Bb}$ & $46 \mathrm{Cc}$ & $58 \mathrm{Bab}$ & $59 \mathrm{Bab}$ & $65 \mathrm{Ca}$ & $62 \mathrm{Bab}$ \\
\hline Mean & 61 & 67 & 63 & 64 & 72 & 70 \\
\hline CV (\%) & \multicolumn{6}{|c|}{6.4} \\
\hline Precipitation (mm) & \multicolumn{6}{|c|}{ Seedling emergence (\%) } \\
\hline 0 & $90 \mathrm{Aab}$ & $92 \mathrm{Aab}$ & $93 \mathrm{Aab}$ & $90 \mathrm{Aab}$ & $88 \mathrm{Ab}$ & $97 \mathrm{Aa}$ \\
\hline 60 & $84 \mathrm{Aa}$ & $83 \mathrm{Ba}$ & $88 \mathrm{Aba}$ & $85 \mathrm{ABa}$ & $83 \mathrm{Aa}$ & $91 \mathrm{ABa}$ \\
\hline 120 & $84 \mathrm{Aa}$ & $82 \mathrm{Ba}$ & $85 \mathrm{Ba}$ & $82 \mathrm{Ba}$ & $84 \mathrm{Aa}$ & $88 \mathrm{Ba}$ \\
\hline 180 & $75 \mathrm{Bb}$ & $78 \mathrm{Bcd}$ & $77 \mathrm{Cd}$ & $89 \mathrm{Aba}$ & 85 Aabc & $80 \mathrm{Cbcd}$ \\
\hline Mean & 83 & 84 & 86 & 87 & 85 & 89 \\
\hline CV (\%) & \multicolumn{6}{|c|}{4.42} \\
\hline Precipitation (mm) & \multicolumn{6}{|c|}{ Corrected vigor index (CVI) } \\
\hline 0 & $393.51 \mathrm{Ab}$ & $471.31 \mathrm{Aa}$ & $512.09 \mathrm{Aa}$ & $499.06 \mathrm{Aa}$ & $500.72 \mathrm{Aa}$ & $468.76 \mathrm{Aa}$ \\
\hline 60 & $337.19 \mathrm{ABC}$ & 434.15 Abab & $377.47 \mathrm{Bbc}$ & 411.05 Bab & $452.39 \mathrm{Aa}$ & 426.46 Aab \\
\hline 120 & $295.48 \mathrm{Bb}$ & $374.35 \mathrm{Bca}$ & $356.05 \mathrm{Bab}$ & $382.98 \mathrm{Ba}$ & $388.36 \mathrm{Ba}$ & $424.64 \mathrm{Aa}$ \\
\hline 180 & $298.89 \mathrm{Bb}$ & $341.77 \mathrm{Cab}$ & $280.36 \mathrm{Cb}$ & $373.45 \mathrm{Ba}$ & $339.67 \mathrm{Bab}$ & 329.34 Bab \\
\hline Mean & 331.27 & 383.42 & 381.49 & 416.63 & 420.29 & 412.3 \\
\hline CV (\%) & \multicolumn{6}{|c|}{8.48} \\
\hline
\end{tabular}

The same uppercase letters in the column (between precipitation levels) and lowercase letters in the row (between cultivars) do not differ from each other by the Tukey test $(p>0.05)$. $C V=$ coefficient of variation.

intense red color (indicating deterioration) and white tissue (indicating death) (Figure 3D).

The physical analyses by the X-ray test showed a significant interaction (cultivars $\times$ precipitation) for the variables of integrated density (Figure 4A) and weathering damage (Figure 4C).

Integrated density was significantly reduced only at the highest level of precipitation applied $(180 \mathrm{~mm})$ to cultivars BMX Apolo and BMX Potência (Figure 4B). Although integrated density did not show significant reductions in most treatments, a clear tendency of reduction in integrated density could be seen with weathering deterioration (Figure 4B). Zones near white on the gray scale [Figure $4 \mathrm{~B}(\mathrm{a})$ ] and red on the color scale [Figure 4B (b)] indicate denser tissues.
Similar to assessments by the tetrazolium test, the increase in the precipitation levels is accompanied by an increase in weathering damage evaluated by the X-ray test in seeds of all the treatments (Figure 4C). Cultivars DM 6563 and BMX Potência exhibited an increase of 57 and 70 p.p. in damage comparing the highest precipitation level (180 mm) with the control (0 mm). Cultivars BMX Apolo and TMG 1175 showed the least weathering damage at the highest precipitation level $(180 \mathrm{~mm})$. In general, these results agree with those observed in the physiological analyses, where DM 6563 and BMX Potência were more susceptible and TMG 1175 was less susceptible to weathering deterioration (Table 1 and Figures $3 \mathrm{~A}$ and $3 \mathrm{~B}$ ).

Signs of weathering damage in soybean seeds are further reinforced by morpho-anatomical 

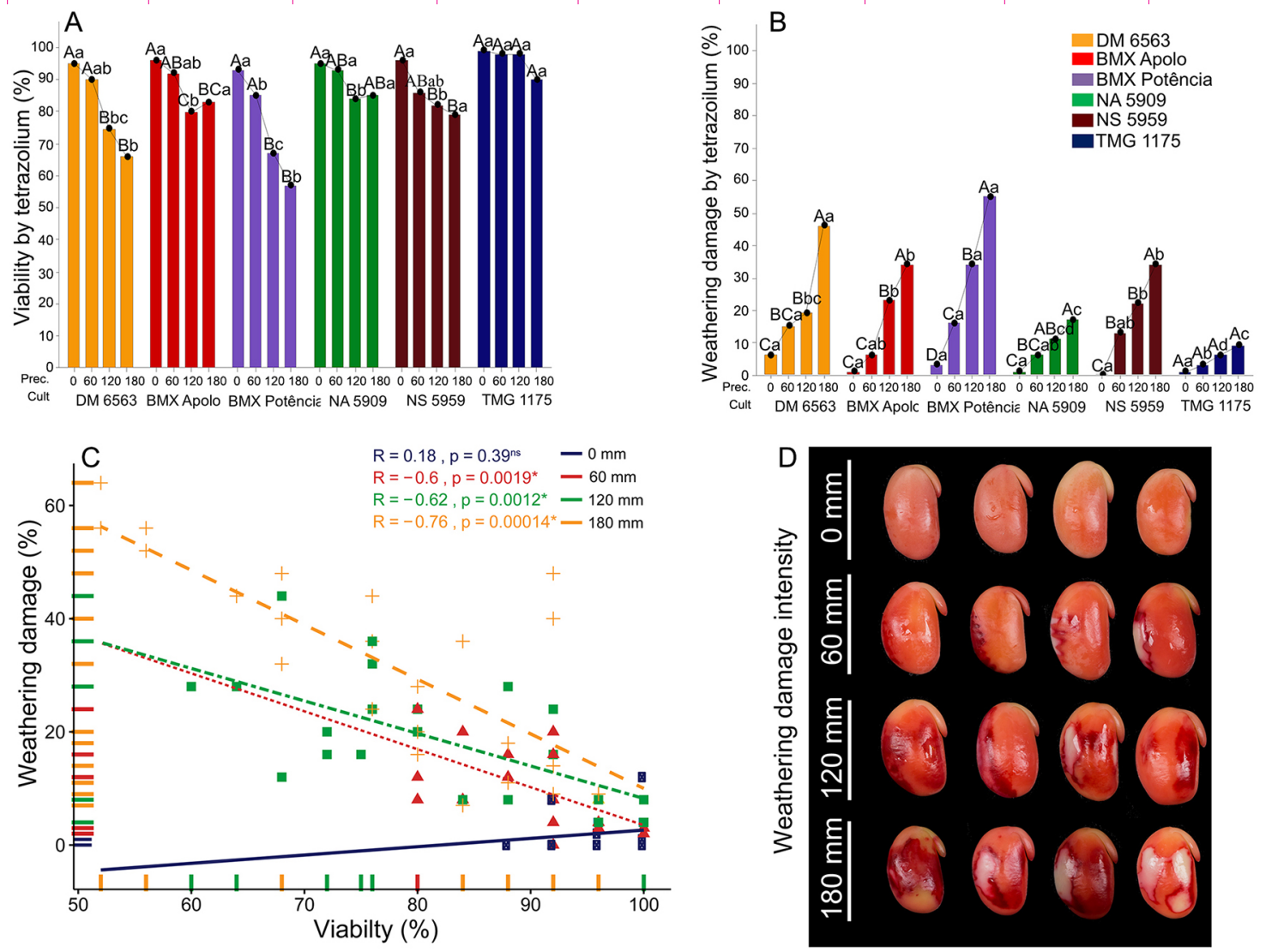

Figure 3 - Viability (A), weathering damage (B), Pearson's correlation between viability and weathering damage (C) and deterioration intensity by the tetrazolium test in soybean seeds under different levels of precipitation (cv. BMX Potência) (D). The same uppercase letters (between precipitation levels) and lowercase letters (between cultivars) do not differ from each other by the Tukey test at $5 \%$ probability. ${ }^{\text {ns }},{ }^{*}=$ not significant and significant by the t test $(p<0.05)$, respectively.

characterization, with a visible difference between seeds without this damage (Figures $5 \mathrm{~A}$ and $5 \mathrm{C}$ ) and with this damage (Figures 5B and 5D). Seeds with this damage are characterized by the wrinkling of the seed coat on the side opposite to the hilum. Anatomically, weathering damage is observed not only by the wrinkling of the seed coat, but also by compaction and rupture of cells, especially of the second (hourglass cell) and third (parenchyma cell) layers (Figures $5 \mathrm{~F}$ and $5 \mathrm{H}$ ), which contrast with the seeds without damage (Figures $5 \mathrm{E}$ and $5 \mathrm{G}$ ).

Small ripples can be seen in the cotyledon tissue, which accompany the wrinkling of the seed coat tissue (Figure 5F). Compaction and rupture of the third and second cell layers are also seen, forming intracellular spaces. However, in the "peak" wrinkling region, these two layers are compacted, hindering their differentiation (Figure 5H). These characteristics were not observed in the seeds of the control treatment (Figures 5E and 5G), reinforcing that the described effects in the seed tissues were caused by weathering.

Considering the results from the PCA, components 1 (PC1) and 2 (PC2) explained approximately $80 \%$ of the total variability of the data (Figure 6A).
The scatter plot (Figure 6A) shows that all cultivars tended to clustering in the control treatments $(0 \mathrm{~mm})$ and the lowest level of precipitation $(60 \mathrm{~mm})$ in the positive scores of component 1 (PC1), corresponding to the regions where the physiological variables (vigor) were concentrated in the correlation circle (Figure $6 \mathrm{~B})$. In contrast, the clustering of the highest levels of precipitation applied ( $120 \mathrm{~mm}$ and $180 \mathrm{~mm}$ ) was observed in the negative scores of PC1 (Figure 6A), corresponding to the location of the variables of weathering damage by the X-ray test (Figure 6B).

The physiological potential vectors (green color) in the correlation circle (Figure 6B) are in opposition to the vector of weathering damage (WD) through the X-ray test (red color), indicating negative correlation between these parameters. Considering the cultivars, in general, clusters of NS 5959, NA 5909, and TMG 1175 were more centered on the PC1 axis, as well as near the vigor vectors (green color), and more distant from the vector WD by the X-ray test (red color). In contrast, cultivars DM 6563 and BMX Potência generally had more dispersed clustering in the correlation plot and the clustering concentrated closer to the weathering damage vector (Figure 6A). 


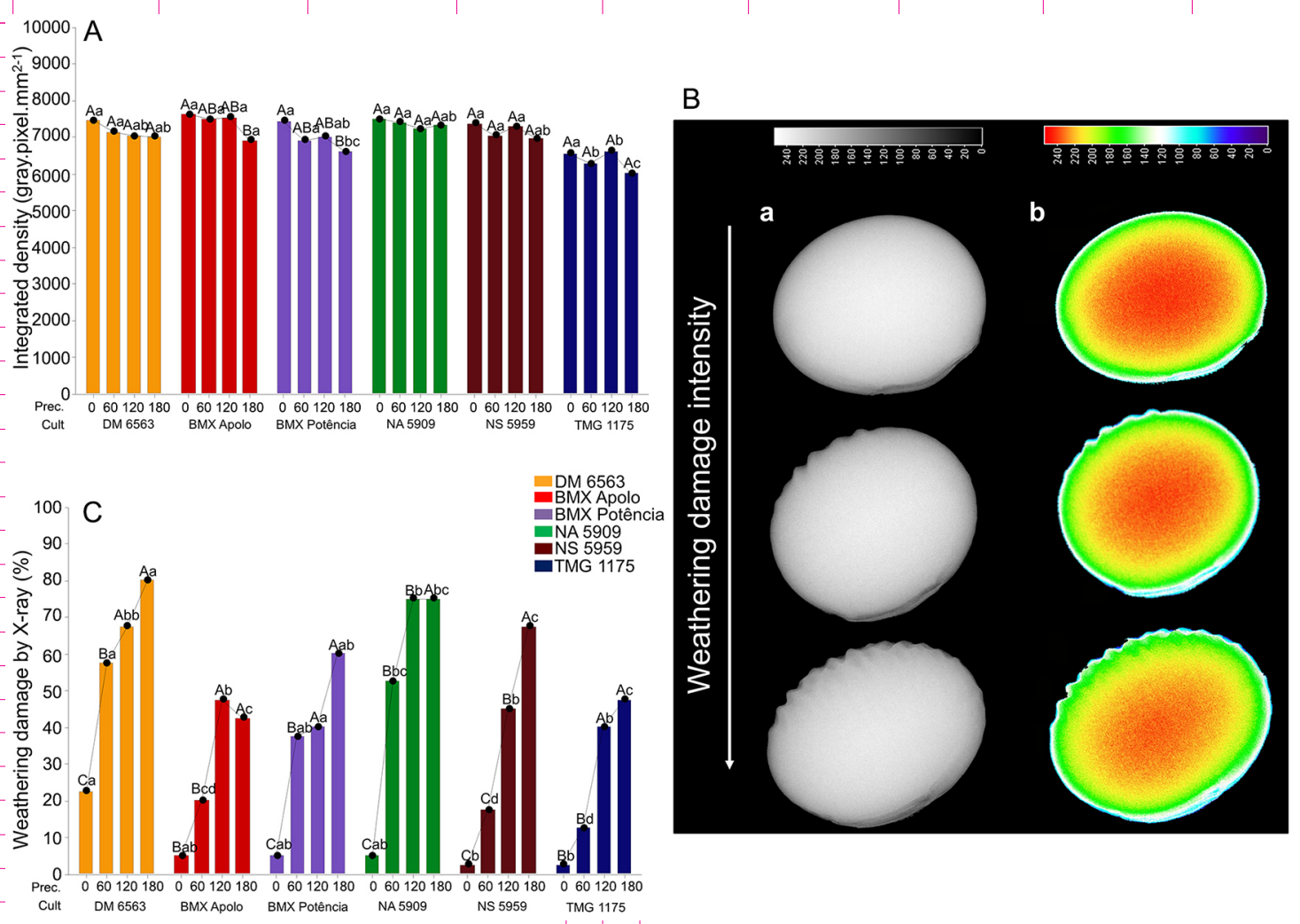

Figure 4 - Integrated density (A), representation of different levels of weathering damage in soybean seeds through X-ray images at gray scale $(B(a))$ and representation of tissue density at color scale $(B(b))$, and weathering damage $(C)$. The same uppercase letters (between precipitation levels) and lowercase letters (between cultivars) do not differ from each other by the Tukey test $(p<0.05)$.

The Pearson's correlation showed that integrated density was not significantly correlated with the physiological variables. A significant negative correlation was also confirmed between the variable of weathering damage by the X-ray test and all the physiological variables analyzed. Furthermore, the physiological variables were positively and significantly correlated with each other (Figure 6C).

\section{Discussion}

The reduction in germination and vigor for the different cultivars was proportional to the increase in the precipitation level, less evident in the control $(0 \mathrm{~mm})$ and at a lower precipitation level $(60 \mathrm{~mm})$, and more evident at the highest levels (120 mm and $180 \mathrm{~mm}$ ). The fact that lower physiological quality and higher levels of precipitation are directly related to the deterioration and increases in respiratory rates, which contribute to degradation of reserves and excessive production of reactive oxygen species (ROS) (Wojtyla et al., 2016; Choudhury et al., 2017; Ochandio et al., 2017). In addition to the increase in respiratory rates, high levels of ROS, and the reduction in seed physiological quality at the higher precipitation levels (120 mm and $180 \mathrm{~mm})$, the seed deterioration was also related to factors, such as inhibition of mitochondrial biogenesis, lower synthesis and mobilization of reserves to the embryo, and others (Deng et al., 2017; Jiang et al., 2018; Ratajczak et al., 2019). In general, the sum of these factors affect cell elongation and formation of the cotyledon hook of seedlings, responsible for emergence through the soil surface, and cause a reduction in field emergence (Finch-Savage and Bassel, 2016; Basso et al., 2018). In this context, it is also important to relate the reduction of germination and vigor with the high values of air temperature $\left(\sim 41{ }^{\circ} \mathrm{C}\right)$ and relative humidity $(\sim 81 \%)$ observed during the application of the precipitation treatments. According to Shu et al. (2020), these characteristics lead to deterioration that resulted in a reduction of seed vigor. The effects of humidity and air temperatures were reinforced by the tetrazolium test that showed deteriorated and dead tissue in seeds under weathering deterioration (especially at the higher precipitation levels $120 \mathrm{~mm}$ and $180 \mathrm{~mm}$ ), confirming that weathering damage resulted in a reduction in the physiological potential of seeds and influenced their tissue integrity. Moreover, the oscillation in seed moisture content observed in the pre-harvest phase is considered one of the main factors related to deterioration and that significantly contributes to a reduction in seed germination and vigor (Malik, 2013; Marcos-Filho, 2016). Furthermore, sensitivity to variation in moisture content 


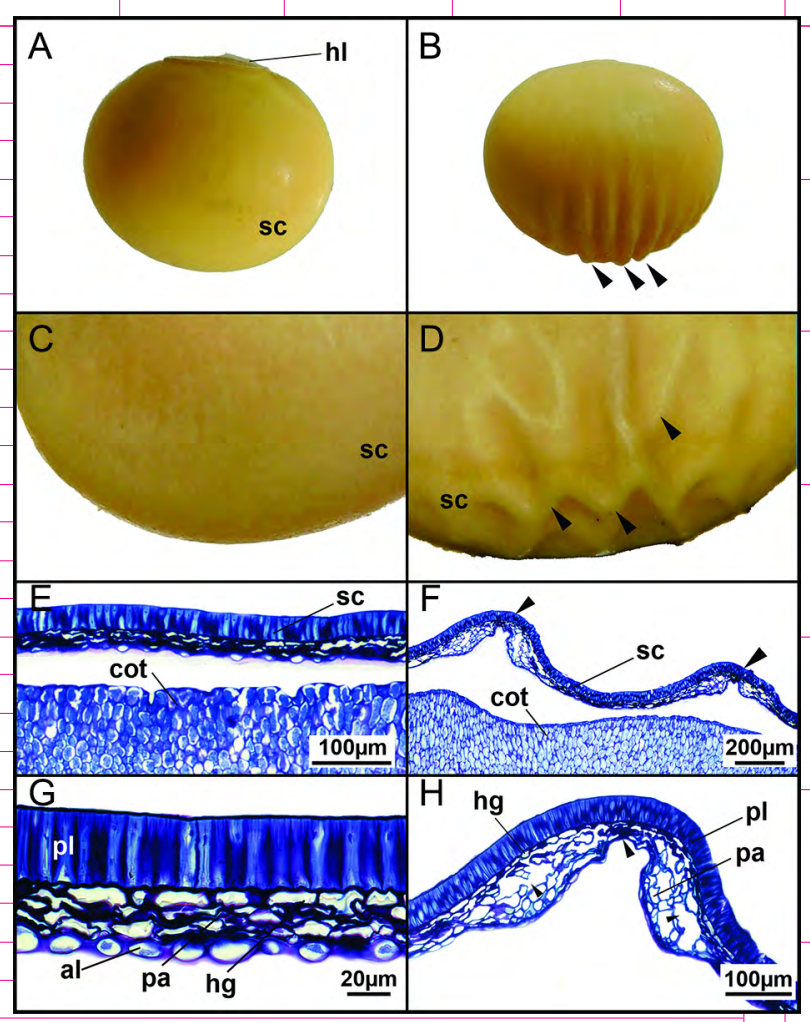

Figure 5 - Morpho-anatomical characterization of soybean seeds with and without weathering damage. Overall perspective of the seed without weathering damage ( $A$ and $C$ ). Overall perspective of the seed with weathering damage ( $B$ and $D)$. Anatomical section of seed without weathering damage ( $E$ and $G$ ). Anatomical section of seed with weathering damage $(\mathrm{F}$ and $\mathrm{H}) . \mathrm{hl}=$ hilum; $\mathrm{sc}=$ seed coat; cot = cotyledon; $\mathrm{pl}=$ palisade layer hg = hourglass cells; $\mathrm{pa}=$ parenchyma tissue; al = aleurone layer. Arrows = seed coat wrinkling and cell rupture.

is directly related to seed composition, which, in the case of soybean, involves processes mainly, such as protein degradation and lipid peroxidation (Xin et al., 2014; Min et al., 2016; 2017).

Gathering all the traits or variables by the PCA could be effective to explain the total data variability observed since the sum of the PC1 and PC2 components was approximately $80 \%$. In this context, together with the Pearson's correlation, the PCA results confirm that weathering deterioration (especially at the highest precipitation levels of $120 \mathrm{~mm}$ and $180 \mathrm{~mm}$ ) significantly contributed to the reduction in seed vigor and, at the same time, favored the increase in weathering damage. In this context, the clustering of the cultivars reinforced the greater susceptibility of DM 6563 and BMX Potência and lower susceptibility of NA 5909 and TMG 1175 to weathering deterioration. Shu et al. (2020) stated that genes involved in photosynthesis, carbohydrate metabolism, lipid metabolism, and heat shock proteins (HSP) pathways might have contributed to the different responses of soybean seeds to deterioration. Thus, these and other factors such as the lignin content (Castro et al., 2016; Huth et al., 2016) may be associated with genetic characteristics related to these diverse responses. All of these observations are important for our future studies with these cultivars involving the use of molecular markers and specific biochemical routes, allowing crop-breeding programs to select tolerant genotypes to weathering deterioration in the field.

The seed analysis through X-ray images has shown potential to evaluate the physical and physiological quality and efficient phenotyping in a non-destructive manner, allowing access to internal and anatomical traits (Xia et al., 2019). This access permitted visual confirmation of a tendency toward reduction in seed tissue density with the increase in weathering damage. This reduction is probably related to the separation of epidermal from hypodermal tissues, exposing them to physical damage and deterioration (Forti et al., 2013). This was observed in the tetrazolium test and morphoanatomical characterization. A lower percentage of damage was observed through the tetrazolium test than through the X-ray test. These results indicated that, depending on the level of injury, external damage is not necessarily reflected internally and detected in the tetrazolium test.

Anatomical characterization showed the rupture and compression of the hourglass cells (second cell layer of the seed coat) that act to softening the effects of expansion, contraction, and rupture of the parenchyma cells when subjected to subsequent hydration and dehydration cycles (Forti et al., 2013; Senda et al., 2017). Therefore, cotyledonary cells of the seeds under simulated precipitation were more exposed to environmental conditions, and their deterioration process increased, which was reinforced by the results of the physiological and X-ray tests. Some studies with soybean seeds subjected to deterioration /whether by moisture, temperature, or harvest delay) report reduction in seed vigor, with differences mainly observed among factors such as genotype and intensity of deterioration (Forti et al., 2013; Castro et al., 2016; Huth et al., 2016; Zuffo et al., 2017).

In synthesis, all these observations through the physiological and physical analyses reinforced the deleterious effects of weathering deterioration on soybean seeds, which differed among genotypes at the pre-harvest phase. Moreover, weathering damage characterized by the wrinkling of the seed coat was directly related to the reduction in soybean seed vigor.

\section{Conclusions}

Weathering deterioration induced by simulated rainfall at the pre-harvest phase contributes to a reduction in soybean seed germination and vigor and is conditioned by the genotype. The increase in the intensity of simulated rainfall leads to greater weathering damage 


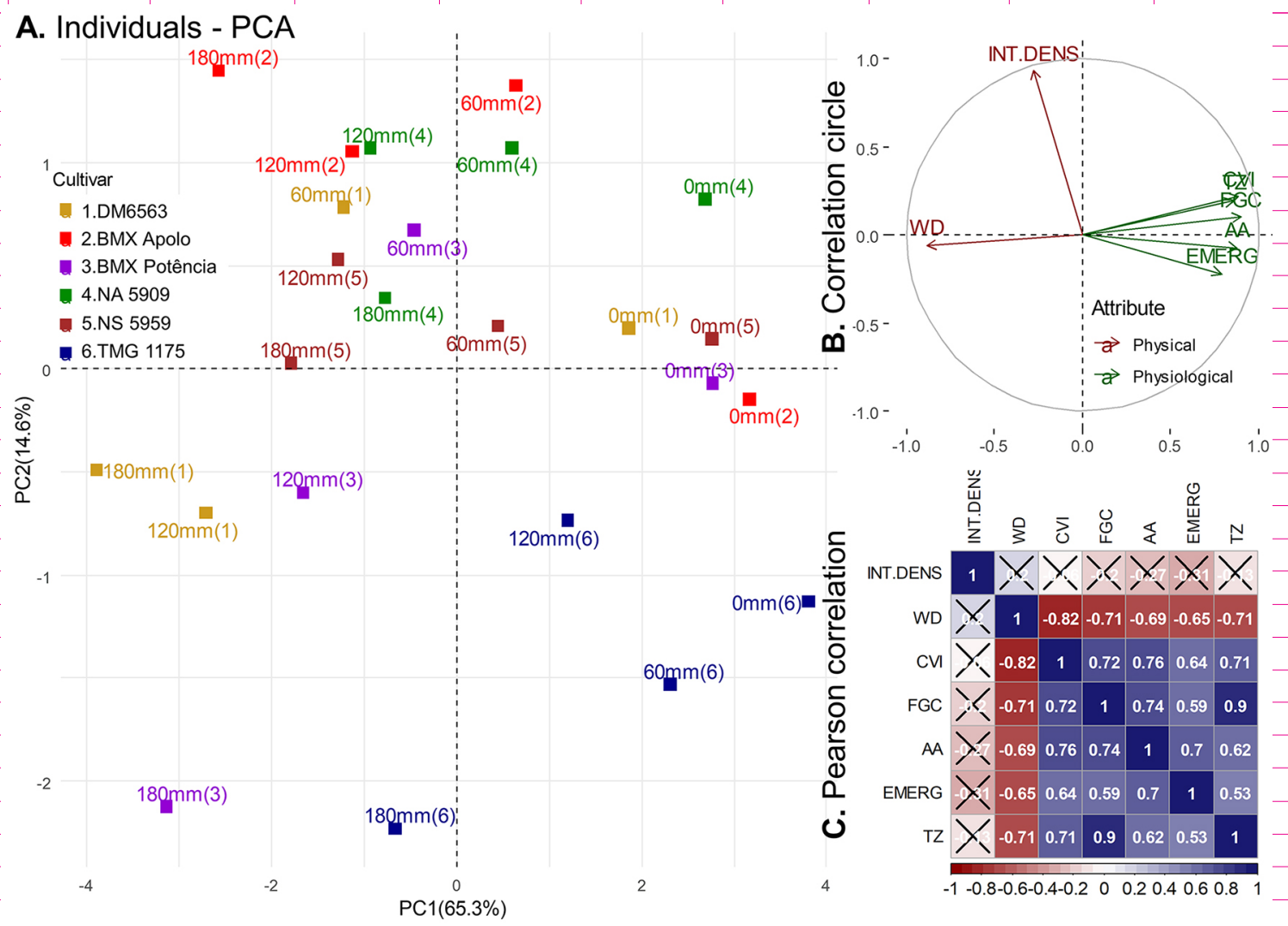

Figure 6 - Principal component analysis (PCA) (A and B) and Pearson Correlation ( $r$ ) (C) obtained by linear combination of the physiological and physical variables in six soybean cultivars under different levels of precipitation. Scatter plot $(A)$ and correlation circle $(B), P C 1=$ principal component 1; PC2 = principal component 2; INT. DENS. = integrated density; WD = weathering damage by the X-ray test; $\mathrm{CVI}=\mathrm{corrected}$ vigor index; $F G C$ = first germination count; $A A=$ accelerated aging; $E M E R G$ = emergence; $E S I$ = emergence speed index; $T Z$ = tetrazolium test. Quadrants marked with " $X$ " in Pearson Correlation (C) represent non-significant correlation $(p>0.05)$ by the t test.

in the seeds, as evidenced by the X-ray and tetrazolium test. The anatomical changes caused by weathering damage in the seeds lead to the cell compaction and rupture, mainly cell layers of the hourglass and parenchyma, forming intracellular spaces. The presence of weathering damage causes a reduction to physiological soybean seed quality.

\section{Acknowledgments}

The authors are thankful to the Federal University of Viçosa (UFV). This study was funded in part by the Coordination for the Improvement of Higher-Level Personnel - Coordenação de Aperfeiçoamento de Pessoal de Nivel Superior (CAPES) - (Funding Code: 001), the Brazilian National Council for Scientific and Technological Development - Conselho Nacional de Desenvolvimento Científico e Tecnológico (CNPq), Minas Gerais State Agency for Research and Development - Fundação de Amparo à Pesquisa do Estado de Minas Gerais (FAPEMIG). Appreciation is extended to Dr. Edgard Augusto de Toledo Picoli (UFV) for his technical support.

\section{Authors' Contributions}

Conceptualization: Pinheiro, D.T.; Dias, D.C.F.S.; Silva, F.L.; Silva, L.J. Data acquisition: Pinheiro, D.T.; Medeiros, A.D.; Ribeiro, J.P.O. Data analysis: Pinheiro, D.T.; Medeiros, A.D.; Silva, L.J. Design of methodology: Pinheiro, D.T.; Dias, D.C.F.S. Writing and editing: Pinheiro, D.T.; Dias, D.C.F.S.; Medeiros, A.D.; Ribeiro, J.P.O; Silva, F.L.

\section{References}

Baek, J.; Lee, E.; Kim, N.; Kim, S.L.; Choi, I.; Ji, H.; Chung, Y.S.; Choi, M.S.; Moon, J.K.; Kim, K.H. 2020. High throughput phenotyping for various traits on soybean seeds using image analysis. Sensors 20: 248.

Basso, D.P.; Hoshino-Bezerra, A.A.; Sartori, M.M.P.; Buitink, J.; Leprince, O.; Silva, E.A.A. 2018. Late seed maturation improves the preservation of seedling emergence during storage in soybean. Journal of Seed Science 40: 185-192.

Bhatia, V.S.; Yadav, S.; Jumrani, K.; Guruprasad, K.N. 2010. Field deterioration of Soybean seed: role of oxidative stress and antioxidant defense mechanism. Journal of Plant Biology 32: 179-190. 
Castro, E.M.; Oliveira, J.A.; Lima, A.E.; Santos, H.O.; Barbosa, J.I.L. 2016. Physiological quality of soybean seeds produced under artificial rain in the pre-harvesting period. Journal of Seed Science 38: 14-21.

Choudhury, F.K.; Rivero, R.M.; Blumwald, E.; Mittler, R. 2017. Reactive oxygen species, abiotic stress and stress combination. The Plant Journal 90: 856-867.

Deng, B.; Yang, K.; Zhang, Y.; Li, Z. 2017. Can antioxidant's reactive oxygen species (ROS) scavenging capacity contribute to aged seed recovery? Contrasting effect of melatonin, ascorbate and glutathione on germination ability of aged maize seeds. Free Radical Research 51: 765-771.

Finch-Savage, W.E.; Bassel, G.W. 2016. Seed vigour and crop establishment: extending performance beyond adaptation. Journal of Experimental Botany 67: 567-591.

Forti, V.A.; Carvalho, C.; Tanaka, F.A.O.; Cicero, S.M. 2013. Weathering damage in soybean seeds: assessment, seed anatomy and seed physiological potential. Seed Technology 35: 213-224.

França-Neto, J.B.; Krzyzanowski, F.C. 2019. Tetrazolium: an important test for physiological seed quality evaluation. Journal of Seed Science 41: 359-366.

França-Neto, J.B.; Krzyzanowski, F.C.; Costa, N.P. 1999. Methodology of the tetrazolium testo $\mathrm{n}$ soybean seeds = Metodologia do teste de tetrazólio em sementes de soja. p. 5-28. In: Krzyzanowski, F.; Vieira, R.; França-Neto, J., eds. Seed vigor: concepts and tests $=$ Vigor de sementes: conceitos e testes. ABRATES, Londrina, PR, Brazil (in Portuguese).

Huth, C.; Mertz-Henning, L.M.; Lopes, S.J.; Tabaldi, L.A.; Rossato, L.V.; Krzyzanowski, F.C.; Henning, F.A. 2016. Susceptibility to weathering damage and oxidative stress on soybean seeds with different lignin contents in the seed coat. Journal of Seed Science 38: 296-304.

International Seed Testing Association [ISTA]. 2020. International Rules for Seed Testing. ISTA, Bassersdorf, Switzerland.

Jiang, F.L.; Bo, L.P.; Xu, J.J.; Wu, Z. 2018. Changes in respiration and structure of non-heading Chinese cabbage seeds during gradual artificial aging. Scientia Horticulturae 238: 14-22.

Johansen, P.A. 1940. Plant Microtechnique. McGraw Hill, New York, NY, USA.

Kassambara, A.; Mundt, F. 2016. Factoextra: extract and visualize the results of multivariate data analyses. R Package Version 1.

Maguire, J.D. 1962. Speed of germination: aid in selection and evaluation for seedling emergence and vigor. Crop Science 2: 176.

Malik, C.P. 2013. Seed deterioration: a review. International Journal of Life Science and Pharma Research 2: 374-385.

Mantovani, E.C.; Bernardo, S.; Palaretti, L. 2009. Irrigation: Principles and Methods = Irrigação: Princípios e Métodos. UFV, Viçosa, MG, Brazil (in Portuguese).

Marcos-Filho, J. 2016. Seed Physiology of Cultivated Plant. ABRATES, Londrina, PR, Brazil.

Marcos-Filho, J. 2015. Seed vigor testing: an overview of the past, present and future perspective. Scientia Agricola 72: 363-374.

Medeiros, A.D.; Zavala-León, M.J.; Silva, L.J.; Oliveira, A.M.S.; Dias, D.C.F.S. 2020. Relationship between internal morphology and physiological quality of pepper seeds during fruit maturation and storage. Agronomy Journal 112: 25-35.
Medeiros, A.D.; Pereira, M.D. 2018. SAPL ${ }^{\oplus}$ : a free software for determining the physiological potential in soybean seeds. Pesquisa Agropecuária Tropical 48: 222-228.

Min, C.W.; Kim, Y.J.; Gupta, R.; Kim, S.W.; Han, W.Y.; Ko, J.M.; Kang, H.W.; Yoon, W.B.; Choung, M.G.; Kim, Y.C.; Kim, S.T. 2016. High-throughput proteome analysis reveals changes of primary metabolism and energy production under artificial aging treatment in Glycine max seeds. Applied Biological Chemistry 59: 841-853.

Min, C.W.; Lee, S.H.; Cheon, Y.E.; Han, W.Y.; Ko, J.M.; Kang, H.W.; Kim, Y.C.; Agrawal, G.K.; Rakwal, R.; Gupta, R.; Kim, S.T. 2017. In-depth proteomic analysis of Glycine max seeds during controlled deterioration treatment reveals a shift in seed metabolism. Journal of Proteomics 169: 125-135.

O'Brien, T.P.; McCully, M.E. 1982. The study of plant structure principles and selected methods. Taxon 31: 789-791.

Ochandio, D.; Bartosik, R.; Gastón, A.; Abalone, R.; Arias Barreto, A.; Yommi, A. 2017. Modelling respiration rate of soybean seeds (Glycine $\max$ (L.)) in hermetic storage. Journal of Stored Products Research 74: 36-45.

Rahman, A.; Cho, B.K. 2016. Assessment of seed quality using non-destructive measurement techniques: a review. Seed Science Research 26: 285-305.

Ratajczak, E.; Małecka, A.; Ciereszko, I.; Staszak, A.M. 2019. Mitochondria are important determinants of the aging of seeds. International Journal of Molecular Sciences 20: 1568.

Santachiara, G.; Borrás, L.; Rotundo, J.L. 2017. Physiological processes leading to similar yield in contrasting soybean maturity groups. Agronomy Journal 109: 158-167.

Senda, M.; Yamaguchi, N.; Hiraoka, M.; Kawada, S.; Iiyoshi, R.; Yamashita, K.; Sonoki, T.; Maeda, H.; Kawasaki, M. 2017. Accumulation of proanthocyanidins and/or lignin deposition in buff-pigmented soybean seed coats may lead to frequent defective cracking. Planta 245: 659-670.

Shu, Y.; Zhou, Y.; Mu, K.; Hu, H.; Chen, M.; He, Q.; Huang, S.; Ma, H.; Yu, X. 2020. A transcriptomic analysis reveals soybean seed pre-harvest deterioration resistance pathways under high temperature and humidity stress. Genome 63: 115-124.

Wojtyla, Ł.; Lechowska, K.; Kubala, S.; Garnczarska, M. 2016. Different modes of hydrogen peroxide action during seed germination. Frontiers in Plant Science 7: 1-16.

Xia, Y.; Xu, Y.; Li, J.; Zhang, C.; Fan, S. 2019. Recent advances in emerging techniques for non-destructive detection of seed viability: a review. Artificial Intelligence in Agriculture 1: 3547.

Xin, X.; Tian, Q.; Yin, G.; Chen, X.; Zhang, J.; Ng, S.; Lu, X. 2014. Reduced mitochondrial and ascorbate-glutathione activity after artificial ageing in soybean seed. Journal of Plant Physiology 171: 140-147.

Zuffo, A.M.; Zuffo Júnior, J.M.; Carvalho, E.R.; Steiner, F.; Zambiazzi, E.V. 2017. Physiological and enzymatic changes in soybean seeds submitted to harvest delay. Pesquisa Agropecuária Tropical 47: 488-496. 